\title{
Knowledge, Attitude and Practice of Breast Self Examination in Female Health Work- ers in Olabisi Onabanjo University Teaching Hospital, Sagamu, Nigeria.
}

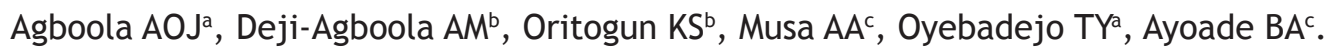

${ }^{a}$ Dept of Morbid Anatomy and Histopathology, ${ }^{b}$ Dept of Medical Microbiology, 'Dept of Surgery, Oachs, Olabisi Onabanjo University, Sagamu, Nigeria

\section{ABSTRACT}

Background:Breast cancer is the leading cause of cancer mortality in women worldwide. This study was designed to assess the knowledge, attitude and practice of breast self examination (BSE) among female health workers in Sagamu. Methods: Questionnaire was used to obtain information such as demographic characteristics, knowledge of breast cancer, attitudes towards BSE and questions relating to practices of BSE from female health workers. Statistical analysis was carried out using descriptive statistics and Chi Square method. Results: The medical doctors had more knowledge about breast cancer than the nurses and laboratory scientists. The medical doctors (81.8\%), laboratory scientists (56.5\%) and the nurses (41.4\%) knew the correct timing and frequency for performance of BSE. The monthly practice of BSE was very low among the nurses (30\%), while only $68.2 \%$ of the doctors and $78.3 \%$ of laboratory scientist admitted carrying out BSE monthly. The doctors (68.2\%), nurses (35.7\%) and laboratory scientist (30.4\%) started BSE below the age of 19 years. Conclusion: The results indicate that the nurses had poor attitude towards BSE and this affected their practice of BSE though they had knowledge. The finding that some of the female health workers did not practice BSE, suggests that there is a need for continuing education programs to change attitude and behaviour towards BSE.

KEY WORDS: Breast Self Examination, Nurses, Doctors

\section{INTRODUCTION}

Breast cancer is the leading cause of cancer mortality in women world wide. ${ }^{1}$ The incidence rates are high in developed countries. ${ }^{1}$ Studies have shown increased incidence from African countries where low rates have previously been reported and an estimated world total incidence of 1.45 million would be expected by the year 2010. ${ }^{1-4}$ The peak age incidence of breast cancer in Nigeria is reported to be between 45-50 years, in contrast to Europe and America where it was reported to be $65-75 y e a r s .{ }^{1,5,6}$ Some cases have been reported below 30 years in Nigeria. ${ }^{7,8}$

Breast diseases often present as palpable masses, inflammatory lesions, nipple secretions, or mammographic abnormalities. ${ }^{9}$ Although mammography remains the best diagnostic tool in the detection of breast cancer it is not routinely performed in Nigeria because of cost, high technology equipment and expertise required. Mammograms miss most breast lump

Corresponding author;

Dr A.O.J Agb00la,

Dept of Morbid Anatomy,

O.A.C.H.S, Olabisi Onabanjo University,

PMB 2022, Sagamu, Nigeria

Email address; johndeji2001@yahoo.co.uk in the younger age group, and this is likely to happen in Nigeria where cases are below the age of 30 have been reported..$^{6-8,10}$ The role of breast self examination in the early diagnosis of breast cancer has been reported..$^{11-13} \mathrm{~A}$ significant number of women present with advanced stages of the disease due to lack of information, knowledge and awareness of early detection measures. ${ }^{14}$ This study was therefore designed to identify the level of breast cancer awareness and BSE knowledge, attitude and practice among female health workers at Olabisi Onabanjo University Teaching Hospital Sagamu.

\section{SUBJECTS AND METHODS}

Study design

This study was as a cross-sectional survey among female health professionals (nurses, medical doctors, and laboratory scientists) of Olabisi Onabanjo Teaching Hospital, Sagamu, Nigeria. The study was conducted in November 2007.

\section{Participants}

Only the female health professionals on morning duty in the hospital on the day of the survey were used as participants in the study. Informed consent of each participant was sought and obtained, and they were 
assured of the confidentiality of their responses.

Instrument

Each participant was given a self-administered questionnaire, which was designed to evaluate information such as socio-demographic data (such as age, marital status, parity and religion); the level of individuals' knowledge of breast cancer (such as what age should BSE start, how often should BSE be performed), the attitude of the participant toward BSE and questions relating to practices of BSE. The questions were designed with Yes, No, or I don't know answers

Analysis

The data were evaluated by descriptive statistics, and

Table I: Demographic Characteristics of the Respondents

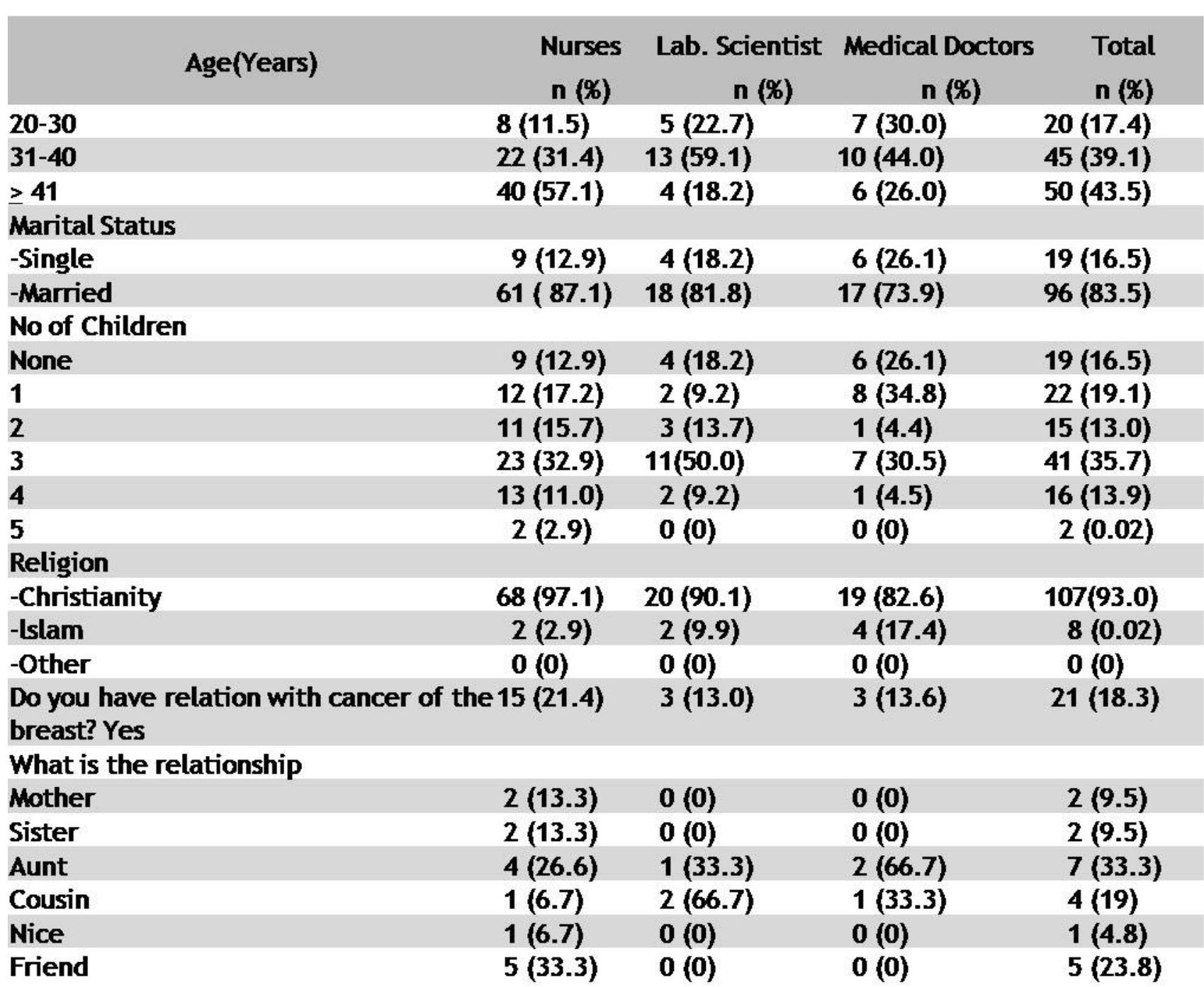

Table II shows the respondents knowledge of breast cancer and BSE. The respondents had good knowledge of breast cancer; more than $88.7 \%$ of them knew that it is common and may be detected with BSE to improve chances of survival of the patients (Table II). There is a significant difference between the number of nurses $(34.5 \%)$, laboratory scientists $(20.0 \%)$ and the doctors $(90.1 \%)$ who believe that both male and female individual should perform BSE $(P<0.05)$. Majority of the respondents $(70.4 \%)$ believe that BSE chi-square. The differences between the three variables were considered significant if the $p$ value was less than 0.05 .

\section{RESULTS}

A total of 115 female Health professionals were interviewed in this study, 70 (60.9\%), 23 (20.0\%), 22 (19.1\%) were nurses, medical doctors and laboratory scientists respectively. There was $100 \%$ response. The result of the demographic information on the respondents is presented in Table I. There is a significant difference in the age of the different groups of respondents $(\mathrm{P}<$ 0.05 ) but no association was established between the marital status of the different groups. 
Table II: Knowledge of Participants about Breast Self Examination (Yes as the answer)

\begin{tabular}{|c|c|c|c|c|}
\hline Question & $\begin{array}{r}\text { Nurses } \\
\mathbf{n}(\%)\end{array}$ & $\begin{array}{l}\text { Lab. } \\
\text { Scientist } \\
n(\%)\end{array}$ & $\begin{array}{l}\text { Doctor } \\
\text { n (\%) }\end{array}$ & $\begin{array}{l}\text { Total } \\
\text { n (\%) }\end{array}$ \\
\hline Have you heard of cancer of the breast? & $70(100)$ & $23(100)$ & $22(100)$ & $115(100)$ \\
\hline $\begin{array}{l}\text { Is it common in this environment? } \\
\text { Can it be detected early? }\end{array}$ & $\begin{array}{l}60(85.7) \\
61(87.1)\end{array}$ & $\begin{array}{l}20(87.0) \\
16(69.6)\end{array}$ & $\begin{array}{l}22(100) \\
22(100)\end{array}$ & $\begin{array}{r}102(88.7) \\
99(86.1)\end{array}$ \\
\hline Can early detection improve chances of survival? & $70(100.0)$ & $23(100)$ & $22(100)$ & $115(100)$ \\
\hline Have you heard of Breast Self Examination? & $70(100)$ & $23(100)$ & $22(100)$ & $115(100)$ \\
\hline \multicolumn{5}{|l|}{ Who should perform BSE? } \\
\hline - Female individual only & $46(65.7)$ & $18(78.3)$ & $2(9.1)$ & $66(57.4)$ \\
\hline \multicolumn{5}{|l|}{ At what age should BSE begin? } \\
\hline$<19$ years & $46(65.7)$ & $18(78.3)$ & $17(77.3)$ & $81(70.4)$ \\
\hline >Above 19 years & $24(34.3)$ & $5(21.7)$ & $5(22.7)$ & 34 (29.6) \\
\hline \multicolumn{5}{|l|}{ How often should BSE be performed? } \\
\hline -Weekly & $23(32.9)$ & $4(17.4)$ & $6(27.3)$ & 33 (28.7) \\
\hline -Monthly & $38(54.3)$ & $19(82.6)$ & $16(72.7)$ & $73(63.5)$ \\
\hline -Yearly & 9 (12.8) & $0(0)$ & $0(0)$ & $9(7.8)$ \\
\hline \multicolumn{5}{|c|}{ When should a woman with regular menstruation do BSE? } \\
\hline - A regular day of each month & $41(58.6)$ & $10(43.5)$ & 4 (18.2) & 55 (47.8) \\
\hline -Within 5 days after menstruation & $29(41.4)$ & $13(56.5)$ & $18(81.8)$ & $60(52.2)$ \\
\hline
\end{tabular}

Issues relating to the attitude to BSE showed that $91.4 \%, 65.2 \%$ and $90.9 \%$ of nurses, laboratory scientists and doctor respectively thought that BSE was necessary (Table III). Nurses (51.6\%), Laboratory Scientists $(66.7 \%)$ and medical doctors $(90.0 \%)$ practiced
BSE because they felt they might have breast cancer in future. Four $(66.7 \%)$ out of the 6 nurses who did not practice BSE claimed they didn't know how to perform BSE (Table III).

Table III: Attitude of participants to Breast Cancer

\begin{tabular}{|c|c|c|c|c|c|}
\hline & Question & $\begin{array}{l}\text { Nurses } \\
\mathrm{n}(\%)\end{array}$ & $\begin{array}{l}\text { Lab Science } \\
\quad \text { n (\%) }\end{array}$ & $\begin{array}{l}\text { Doctor } \\
\text { n (\%) }\end{array}$ & $\begin{array}{l}\text { Total } \\
\text { n (\%) }\end{array}$ \\
\hline 1 & Do you think BSE is necessary? & $64(91.4)$ & $15(65.2)$ & $20(90.9)$ & $99(86.1)$ \\
\hline 2 & Have you done BSE before? & $64(91.4)$ & $15(65.2)$ & $20(90.9)$ & $99(86.1)$ \\
\hline 3 & If yes- why? & & & & \\
\hline a. & I might have breast cancer in future. & 33 (51.6) & $10(66.7)$ & $18(90.0)$ & $61(53.0)$ \\
\hline b. & To examine my breast regularly. & $9(14.1)$ & $3(20.0)$ & $1(5.0)$ & $13(11.3)$ \\
\hline c. & Check the progression of any lump. & $10(15.6)$ & $1(6.7)$ & $1(5.0)$ & $12(10.4)$ \\
\hline d. & Doctors advice & $1(1.6)$ & $0(0)$ & $0(0)$ & $1(0.01)$ \\
\hline e. & Breast pain & $4(6.3)$ & $1(6.7)$ & $0(0)$ & $5(0.04)$ \\
\hline f. & Nipple discharge & $0(0)$ & $0(0)$ & $0(0)$ & $0(0)$ \\
\hline g. & Feeling of a mass & $2(3.1)$ & $0(0)$ & $0(0)$ & $2(0.02)$ \\
\hline h. & Breast cancer in the Family & $2(3.1)$ & $0(0)$ & $0(0)$ & $2(0.02)$ \\
\hline i. & Other (Specify) & $3(4.7)$ & $0(0)$ & $0(0)$ & $3(0.03)$ \\
\hline 4 & If no - why? & $6(8.6)$ & $8(34.8)$ & $2(9.1)$ & $16(0.14)$ \\
\hline a. & I don't know how to do it & $4(66.7)$ & $6(75.0)$ & $0(0)$ & $10(0.09)$ \\
\hline b. & I don't think it is important & $1(16.7)$ & $0(0)$ & 1 (5.0) & $2(0.02)$ \\
\hline c. & I don't believe in the efficiency of the test & $0(0)$ & $0(0)$ & $\mathbf{O}(0)$ & $0(0)$ \\
\hline d. & I don't have any symptom & $1(16.7)$ & $0(0)$ & $1(50.0)$ & $2(0.02)$ \\
\hline e. & I know I can never have cancer & $0(0)$ & $1(12.5)$ & $\mathbf{O}(0)$ & $1(0.01)$ \\
\hline f. & I am scared of being diagnosed with cancer of breast & $0(0)$ & $1(12.5)$ & $0(0)$ & $1(0.01)$ \\
\hline \multirow[t]{4}{*}{5} & $\begin{array}{l}\text { What are your opinions about the breast } \\
\text { examination? }\end{array}$ & & & & \\
\hline & -Embarrassing & $5(7.1)$ & $O(0)$ & $6(27.3)$ & $11(0.10)$ \\
\hline & -Crude and disgusting & $1(1.4)$ & $1(4.3)$ & $1(4.5)$ & $3(0.03)$ \\
\hline & -Very painful & $0(0)$ & $1(4.3)$ & $0(0)$ & $1(0.01)$ \\
\hline
\end{tabular}


The level of practices of BSE among the respondents is presented in table IV. Only $30 \% ; 78.3 \%, 68 \%$ of the nurses, laboratory scientist and doctors respectively perform BSE regularly (12 times per year) the difference between these groups is statistically significant $(p<0.05)$. Only $28.6 \%$ of the nurses, $17.4 \%$ labora-

Table IV: Level of Practices of Breast Self Examination tory scientist and $72.7 \%$ medical doctors performed BSE within 5 days after menstruation and the difference was statistically significant $(P<0.05)$. The doctors $(68.2 \%)$, nurses $(35.7 \%)$ and laboratory scientist $(30.4 \%)$ started BSE before 19 years of age.

\begin{tabular}{|c|c|c|c|c|}
\hline & Question & $\begin{array}{l}\text { Nurses } \\
\mathrm{n}(\%)\end{array}$ & $\begin{array}{c}\text { Lab Scientist } \\
\text { n (\%) }\end{array}$ & $\begin{array}{l}\text { Doctor } \\
\text { n (\%) }\end{array}$ \\
\hline 1 & How often do you perform BSE in a year? (12 times) & 21(30) & $18(78.3)$ & $15(68.2)$ \\
\hline \multirow[t]{3}{*}{2} & At what age did you start BSE? & & & \\
\hline & $<19$ years & $24(35.7)$ & $7(30.4)$ & $15(68.2)$ \\
\hline & Above 19 years & $40(57.1)$ & $16(69.6)$ & $7(31.8)$ \\
\hline \multirow[t]{3}{*}{3} & What time do you normally perform BSE? & & & \\
\hline & - A regular day of each month & $44(62.9)$ & $19(86.6)$ & $6(27.3)$ \\
\hline & - Within 5 days after menstruation & $20(28.6)$ & $4(17.4)$ & $16(72.7)$ \\
\hline \multirow[t]{3}{*}{4} & Have you had a breast examination in the last three years? & & & \\
\hline & - YES & $62(88.6)$ & $18(78.3)$ & $18(81.8)$ \\
\hline & - NO & 8 (11.4) & $5(21.7)$ & $4(18.2)$ \\
\hline \multirow[t]{5}{*}{5} & When was the last time you performed BSE? & & & \\
\hline & - Weeks & $22(31.4)$ & $18(78.3)$ & $14(63.6)$ \\
\hline & - Months & $40(57.1)$ & $4(17.4)$ & $4(18.2)$ \\
\hline & - Years & $8(11.4)$ & $1(4.3)$ & $4(18.2)$ \\
\hline & Where was the examination done? & & & \\
\hline \multirow[t]{5}{*}{6} & - At home & $46(65.7)$ & $17(73.9)$ & $16(72.7)$ \\
\hline & - Family planning center & $5(7.1)$ & $\mathbf{O}(0)$ & $0(0)$ \\
\hline & - Private hospital & $6(8.6)$ & $1(4.3)$ & $3(13.6)$ \\
\hline & - Public hospital & $7(10)$ & $0(0)$ & $3(13.6)$ \\
\hline & - Free screening programme & $\mathbf{0}(0)$ & $\mathbf{0}(0)$ & $0(0)$ \\
\hline
\end{tabular}

\section{DISCUSSION}

The value of BSE in the early diagnosis of breast cancer has been emphasized by several authors. ${ }^{11,}{ }^{12}$ This study showed that the majority of the respondents had knowledge of breast cancer and breast self-examination. This is expected considering the fact that they are health professionals and must have acquired this knowledge during their educational training. Previous studies have reported the roles played by formal and non-formal education in health related issues. ${ }^{15}$, 16

The knowledge of the nurses in the present study on the correct frequency and timing of BSE in women with regular and irregular menstrual cycle is below average. Although this finding agrees with the study done elsewhere in Nigeria but it differs in terms of knowledge of the correct timing for women with regular menstruation. ${ }^{17,18}$

The role of age in the frequency of practice BSE is controversial, while some study found a negative association between age and BSE; others reported a positive relationship between age and BSE. ${ }^{19-21}$ In another, no differences were observed in age and the frequency BSE. ${ }^{22}$ There is a significant difference between the doctors, nurses and the laboratory scientist who started performing BSE below the age of 19 years

in the present study, greater than half of the doctors started BSE earlier and practiced it on a monthly basis compared with the nurses.

Positive associations have been demonstrated between educational level and BSE frequency and practice, although one study found no difference between educational groups in the frequency of BSE. ${ }^{19,23}$ The doctors performed BSE in a more regular and timely manner compared to the nurses. They may have been more conscious of BSE or have been affected by information received during their medical training or cases seen in their careers. However, it is interesting to note that less than half of the nurses in this study performed BSE. This agrees with the report of an author who found that fewer than half of 300 nurses in United States regularly performed BSE. ${ }^{24}$ Although the nurses in this study had knowledge of BSE, this is not reflected in their attitude and practice.

Cavdar, et al 2007 reported that most female physicians and nurses (65\% and 70\% respectively) believed that BSE was unnecessary. ${ }^{13}$ However, the finding of $86.1 \%$ of the female professionals in this study who 
believed that BSE is necessary is in agreement with the study of Rosvold et al 2001, who reported that only $6 \%$ of female physicians believed that BSE was unnecessary. ${ }^{25}$

Breast cancer occurs mainly in women but occasionally in men. Most people do not realize that men also have breast tissue and can develop breast cancer. A study conducted in Nigeria reported 1 male patient in 100 cases of breast cancer. ${ }^{26}$ Interestingly, a significant number of nurses and laboratory scientist do know that both male and female should perform BSE. This could probably be because they have not come across one or they were not taught in the course of their training.

The finding that some of the female health workers did not practice BSE, suggests that there is a need for continuing education programs to change attitude and behaviour towards BSE. Since, the main reason provided was forgetfulness and "I don't know how to perform it"; they may have difficulty in motivating the general population to perform BSE.

\section{CONCLUSION}

The results indicate that the nurses have poor attitude towards BSE and this affected their practice of BSE although they had knowledge. The finding that some of the female health workers did not practice BSE suggests that there is a need for continuing education programs. Emphasis should be laid on BSE in undergraduate and postgraduate courses, especially for nurses, as they are mostly involved in patient education. Also, provision of BSE educational programs is necessary for all health workers to increase their knowledge, confidence, performance and teaching of BSE.

\section{REFERENCE}

1. Parkin M.D, Pisani P, Ferlay J. Global Cancer Statistics. CA Cancer J Clin 1999; 49:33-64

2. Adebamowo CA, Ajayi A. Breast Cancer in Nigeria. West Afr J Med 2000; 19:179-91

3. Thomas JO. Cancer Registration and Diagnosis in Ibadan. Arch Ibadan Med 2000; 1:5-6

4. American Cancer Society. Cancer Facts and Figures. 2005 (http: / /www.cancer.org).

5. Abudu EK, Banjo AAF, Izegbu MC, Agboola AOJ, Anunobi CC, Musa A. Malignant Breast lesions at Olabisi Onabanjo University Teaching Hospital (OOUTH) Sagamu-a histopathological review. Nigeria Postgrad Med J. 2007; 14:57-9

6. Anyanwu SN. Breast cancer in eastern Nigeria: A ten year review. West Afr J Med 2000; 19:120-5

7. Banjo AAF. Overview of Breast Cancer and Cervical Cancer in Nigeria: are there regional variations? Paper presented at International workshop on new trends in the management of breast and cervical cancers, Lagos, Nigeria 2004.

8. Okobia MN, Osime U. Clinicopathological study of carcinoma of the breast in Benin City. Afr J Reprod Health 2001; 5:56-62

9. Cotrans RS, Kumar V, Robbins SL. The Breast. In: Robbins Pathologic Basis of Diseases. 5th edition. Philadelphia: WB Saunders, 1994:1090

10. Wu TY, Yu MY: Reliability and validity of the mammography screening beliefs questionnaire among Chinese American Women. Cancer Nursing 2003; 26:131-42

11. Ali Abu-Salem OT, Abdulla Hassan M. Breast Self-Examination among Female Nurses in Jordan. Shiraz Med J 2007; 8(2)

12. Kern KA. Medicolegal analysis of the delayed diagnosis of Cancer in 338 cases in the United States. Arch Surg 1994; 129:397-403

13. Çavdar Ý, Akyolcu N, Özbaș A, Öztekin D, Ayoğlu T, Akyüz. N. Determining female physicians' and nurses' practices and attitude towards breast self examination in Istanbul, Turkey. Oncol Nurs Forum 2007; 36:1218-21

14. Çeber E, Soyer MT, Ciceklioglu M, Cimat S. Breast cancer risk assessment and risk perception on nurses and midwives in Bornova Health District in Turkey. Cancer Nurs 2006; 29:244-9

15. Ibrahim EM, Al-Idrissi HY, Al-Khadra AH, Kurashi NY, Al-Jishi FM, Said I, et al. Women's knowledge of and attitude towards breast cancer in a developing country. Implications of program interventions. Results based on interviewing 500 women in Saudi Arabia. J Cancer Educ 1991; 6:73-81

16. Okobia MN, Bunker $\mathrm{CH}$, Okonofua FE Osime U. Knowledge, attitude and practice of Nigerian women towards breast cancer: A cross-sectional study. World J Surg Oncol 2006; 4:11

17. Odusanya 00, Tayo 00. Breast cancer knowledge, attitudes and practice among nurses in Lagos, Nigeria. Acta Oncol 2001; 40:844-8

18. Demirkiran F, Balkaya N A, Memis S, Turk G, Ozvurmaz S, Tuncyurek P. How do nurses and teachers perform breast self-examination: are they reliable sources of information? BMC Public Health 2007; 7:96

19. Smith EM, Francis AM, Polissar L. The effect of breast self-exam practices and physician examinations on extent of disease at diagnosis. Prev Med 1980; 9:409-17

20. Senie RT, Rosen PP, Lesser ML, Kinne DW. Breast self-examination and medical examination related to breast cancer stage. Am J Public Health 1981; 71:583-90

21. American Cancer Society: Public attitudes toward cancer and cancer tests. Cancer J Clin 1980; 30:92-8 
22. Holtzman D, Celentano DD. The practice and efficacy of breast self-examination: A critical review. Am J Public Health 1983; 73:1324-6

23. Reeder S, Berkanovic E, Marcus AC. Breast cancer detection behavior among urban women. Public Health Rep 1980; 95:276-81

24. Devine SK, Frank DI. Nurses self-performing and teaching others breast self-examination: Implication for advanced practice nurses. Clin Excel Nurse Pract 2000; 4:216-23

25. Rosvold EO, Hjartaker A, Bjertness E, Lund E (2001). Breast self examination and cervical cancer testing among Norwegian female physicians. A nation-wide comparative study. Soc Sci Med; 52:249-58

26. Atoyebi OA, Atimomo CE, Adesanya AA, Bredugo BK, Rocha Afodu JT. An Appraisal of 100 patients with Breast Cancer seen at the Lagos University Teaching Hospital. Nig Quart J Hosp Med 1997; 2:104-8. 